\title{
ACCUMULATION OF NUTRIENTS IN THE RAW OF CRAMBE L. SPECIES
}

\section{Vergun Olena*, Shymanska Oksana, Rakhmetov Dzhamal, Fishchenko Valentyna, Bondarchuk Oleksandr, Rakhmetova Svitlana}

\author{
M.M. Gryshko National Botanical Garden of the NAS of Ukraine, Kyiv, Ukraine
}

Received: 29. 11. 2019 Revised: 1. 12. $2019 \quad$ Published: 6. 12. 2019

Investigation of accumulation of different compounds in above-ground part of these plants an important aspect for evaluation of perspective of use. The aim of this study was to compare the peculiarities of the biochemical composition of Crambe species dynamically. Plant material collected from the experimental collection of M.M. Gryshko National Botanical Garden of the NAS of Ukraine. It was studied above-ground parts of $C$. cordifolia Steven, $C$. koktebelica (Junge) N. Busch, C. maritima L., C. steveniana Rupr. At the spring vegetation, budding stage, flowering, and fruitage. Following biochemical parameters was studied: dry matter by drying to consist weight at the $105{ }^{\circ} \mathrm{C}$; content of sugars by Bertrand's method using of glucose scale; ascorbic acids with 2.6-dichlorophenolindophenol, tannins with indigo carmine discoloration, organic acids by sodium hydroxide titration with phenolphthalein; carotene with gasoline galosh spectrophotometrically; ash in muffle over. The dry matter during vegetation was from 9.76 (C. cordifolia, budding) to 22.54 (C. maritima at the fruitage) \%, total content of sugars from 6.54 (C. maritime at the fruitage) to 33.18 (C. cordifolia at the budding) \%, ascorbic acid from 139.85 (C. maritima at the spring vegetation) to 987.02 (C. maritime at the budding) $\mathrm{mg} \%$, $\beta$-carotene from 0.39 (C. maritima at the budding) to 1.82 (C. cordifolia at the fruitage) $\mathrm{mg} \%$, tannins from 1.28 (C. cordifolia at the fruitage) to 7.47 (C. steveniana at the budding) \%, content of organic acids from 3.12 (C. steveniana at the fruitage) to 6.28 (C. koktebelica at the spring vegetation) \%, ash from 6.11 (C. maritima at the spring vegetation) to 14.61 (C. cordifolia at the flowering) \%. Correlation analysis showed that between the content of tannins and organic acids existed positive moderate correlation $(r=0.52)$. Between other parameters found the weak, very weak positive or negative correlation. Thus, comparing biochemical analyze identified that raw of four species of Crambe is a valuable source of nutrients during vegetation. The high content of sugars, ascorbic acid, and carotene can recommend these plants as forage crops. Also, raw of these plants can be recommended for farther pharmacological investigations.

Keywords: Crambe, biochemical composition, raw

*Corresponding author: Olena Vergun, M.M. Gryshko National Botanical Garden of Ukraine of National Academy of Sciences, Kyiv, Timiryazevska 1, 01014 Kyiv, Ukraine $\triangle$ en vergun@ukr.net 


\section{Introduction}

Plants from Brassicaceae Burnett have a long story of an important role in human life as food, forage, medicinal plants, etc. They are source of biologically active compounds that determine their pharmacological properties (Raiola et al., 2018; Shankar et al., 2019). Chemical investigation of Brassicaceae characterized by presence of phytonutrients such as tocopherols, vitamin E, carotenoids, polyphenol compounds, amino acids, glucosinolates, etc. (Avato and Argentieri, 2015). Oil plants from this family revealed antioxidant activity by DPPH method in methanol extracts as well as in water extracts (Rakhmetov et al., 2018).

Genus Crambe L. has a wide area of distribution in the world (Prina, 2009). Species of Crambe genus are very promising species due to their biological and biochemical properties (Kalista, 2017). They belong to the Brassicaceae and in the flora of Ukraine there are 8 species (Iljinska et al., 2007). The most known and useful plants from Brassicaceae are the source of oil, content of which can be varied from 17 to $40 \%$ and upper (Vergun et al., 2017a). Crambe abissinica the most known species last time due to content of oil and other nutrients such as protein, amino acids, phenolic compounds, etc. (Lovatto et al., 2017). Also, the utilization of oil produced by C. abissinica is favored over high erucic acid rapeseed oil due to its higher natural content of C22:1 (Zorn et al., 2019). According to Stankevych (2017), plants of this species are high-yield cultures, which may compete with other oil cultures of Brassicaceae by a complex of parameters.

Under-ground parts of Crambe cordifolia are the rich source of polyphenol compounds with antioxidant activity as showed the study of different extracts. Also, they exhibited antimicrobial activity (Rashid et al., 2018).

The aim of the research is the determination of selected biochemical compounds in the raw of the above-ground part of plants of Crambe species, taking into account that there is limited information about accumulation some nutrients.

\section{Materials and methodology}

\section{Biological material}

It was investigated species of the genus of Crambe: $C$. cordifolia Steven, C. koktebelica (Junge) N. Busch, C. maritima L., C. steveniana Rupr. An experiment carried out during 2018-2019 at the laboratory of Cultural Flora Department of M.M. Gryshko National Botanical Garden of the NAS of Ukraine. Plants samples took at the start of spring growth, budding stage, flowering stage, and fruitage. All investigated plants are perennial.

\section{Biochemical analyses}

\section{Dry matter determination}

Plant samples were dried in drying oven at the $105^{\circ} \mathrm{C}$ till constant weight in aluminum boxes. Results are given in percentages (Hrytsajenko et al., 2003). 


\section{Total content of sugars determination}

The total content of sugars was investigated by Bertrand's method in water extracts. $4 \mathrm{~g}$ of fresh mass mixed and homogenized with distilled water (approximately $50 \mathrm{ml}$ ) in the $100 \mathrm{ml}$ test-tubes and heated in the water bath at $70{ }^{\circ} \mathrm{C}$ during $15-20 \mathrm{~min}$. After cooling in the obtained mixtures added $1 \mathrm{ml}$ of phosphate-oxalate mixture. After this was added $1.5 \mathrm{ml}$ of lead acetate. The obtained mixture brings to the mark $(100 \mathrm{ml})$ with water. After filtration from obtained solution took $50 \mathrm{ml}$ and mixed with $8 \mathrm{ml}$ of $20 \% \mathrm{HCl}$ (at the $70{ }^{\circ} \mathrm{C}$ in water bath for $5 \mathrm{~min}$ ) and after cooling was neutralized by $12 \% \mathrm{NaOH}$ and brought to the mark by distilled water $(100 \mathrm{ml}) .3 \mathrm{ml}$ of obtained solution mixed with $6 \mathrm{ml}$ of Fehling's solution reagent ( $6 \mathrm{~min}$ boiling in the water bath). Obtained mixture analyzed for total content of sugars. Results are given by percentages (Hrytsajenko et al., 2003).

\section{Total content of ascorbic acid}

Determination of ascorbic acid content conducted by method offered by K. Murri. $2 \mathrm{~g}$ of fresh mass mixed with $50 \mathrm{ml}$ of $2 \%$ oxalic acid. Obtained mixture put into the dark for $20 \mathrm{~min}$. Content of ascorbic acid of obtained extracts determined by a 2.6-dichlorophenol-indophenol method that based on the reduction properties of ascorbic acid. Obtained results expressed in the mg\% DW (Hrytsajenko et al., 2003).

\section{Total content of carotene}

The concentration of total carotene determined according to Pleshkov (1985) using extraction with rubber solvent (petrol). $1 \mathrm{~g}$ of absolutely dried raw mixed with $20 \mathrm{ml}$ of Kalosha petrol for 2 hours. After this obtained filtrate measured spectrophotometrically at the wavelength $440 \mathrm{~nm}$ at the Unico spectrophotometer. Obtained results expressed in $\mathrm{mg} \% \mathrm{DW}$.

\section{Total content of tannins}

The content of tannins was determined with indigo carmine as indicator (Ermakov et al., 1972). $5 \mathrm{~g}$ of fresh mass mixed with distilled water (approximately $50 \mathrm{ml}$ ) in $100 \mathrm{ml}$ tastetubes. Obtained mixture heated in the water bath at $70{ }^{\circ} \mathrm{C}$ for 2 hours. After cooling, adding water to the $100 \mathrm{ml}$ and following filtration $10 \mathrm{ml}$ of filtrate used for determination of total content of tannins. This procedure used $700 \mathrm{ml}$ distilled water and $25 \mathrm{ml}$ of $1 \%$ solvent of indigo carmine. Obtained results expressed in \%.

\section{Total content of organic acids}

The total content of organic acids determined with phenolphthalein and results calculated with malic acid coefficient (Krishchenko, 1983). $10 \mathrm{ml}$ of filtrate (the same procedure described for determination of total content of tannins) titrated with $1 \mathrm{~N}$ solvent of $\mathrm{NaOH}$ in presence of phenolphthalein. Obtained results expressed in percentages.

\section{Total content of ash}

The total content of ash determined by combustion in oven at the $300-700{ }^{\circ} \mathrm{C}$ for 3 days with step increasing of temperature (Hrytsajenko, 2003). 


\section{Statistical analysis}

Experimental data were analyzed using Excel 2016. Correlation analysis was performed using Pearson's criterion. Mean values of three replicates and standard deviations given in Figures $1-7$.

\section{Results and discussion}

Plants of the Crambe genus in M.M. Gryshko Botanical Garden have grown and have investigated in collection of forage plants last some decades. Previous studies concerning their antioxidant activity and accumulation of nutrients in the underground parts of plants (Vergun et al., 2018).

We determined that the content of dry matter during vegetation was from 9.76 to $22.54 \%$ depending on species and stage of growth (Figure 1). The dry weight of different microgreens Brassicaceae according to Xiao et al. (2016) was 4.9-10.3\% depending on species. Other species from this family Camellina sativa L., their cultivars and varieties had dry matter content in range 18.13-23.38\% in stage of flowering (Vergun et al., 2017b).

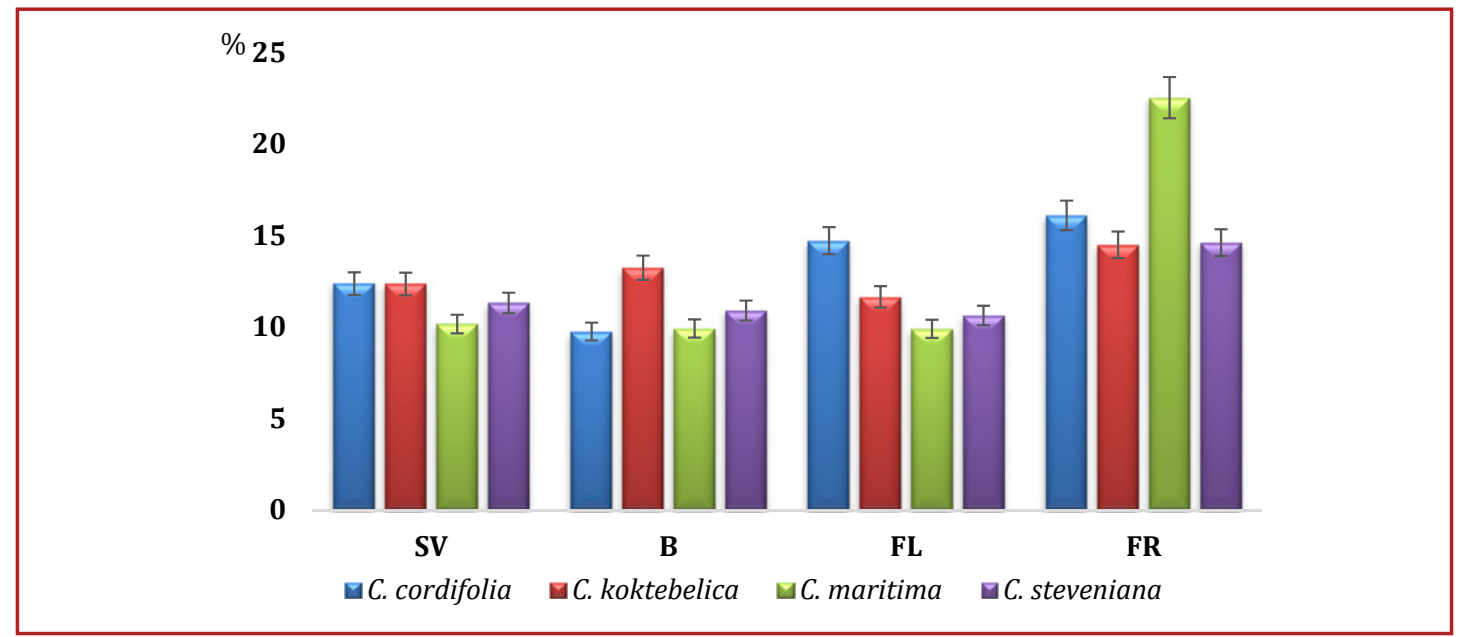

Figure 1 Total content of dry matter in the above-ground part of plants of Crambe spp. SV - spring vegetation; B - budding stage; FL - flowering stage; FR - fruitage

The total content of sugars in the Crambe species determined from 6.54 to $33.18 \%$ (Figure 2 ). It should be noticed that $C$. cordifolia demonstrated the most content of sugars in the stage of budding. Also, high content of sugars found in C. steveniana in the period of flowering. Minimal value of this parameter fixed in the fruitage for C. maritima. Plants of Camellina sativa had content of sugars in range of 4.76-8.12\% in stage of flowering (Vergun et al., 2017b). As reported Rosa et al. (2001), total content of sugars in broccoli cultivars was $114.5-229.2 \mathrm{mg} / \mathrm{g}$. 


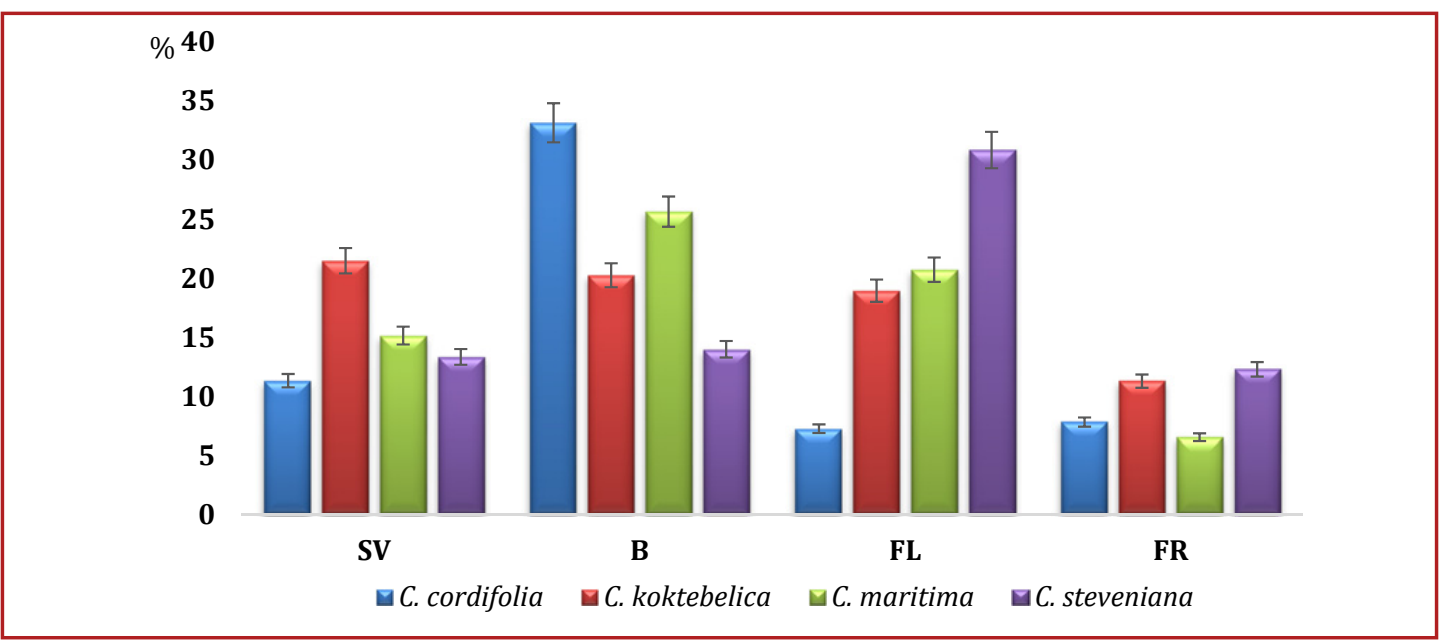

Figure 2 Total content of sugars in the above-ground part of plants of Crambe spp. $\mathrm{SV}$ - spring vegetation; B - budding stage; FL - flowering stage; FR - fruitage

Ascorbic acid plays an important role as co-factor for some enzymes and acts in numerous processes. It demonstrated strong antioxidant activity that makes this compound wide distributed in the cosmetic industry (Golonka et al., 2017). As reported Lokato et al. (2013), ascorbic acid participates in some physiological processes such as immune stimulation, synthesis of collagen, hormones, iron absorption, etc. The content of ascorbic acid varied from 139.85 to $987.02 \mathrm{mg} \%$ DW depending on species (Figure 3). Plants of Camellina sativa had value of this parameter in range of 207.23-410.23 mg\% DW (Vergun al., 2017b). Other cruciferous species as Armoracia rusticana had ascorbic acid content in leaves up to $350 \mathrm{mg} \%$ FW (Rivelli et al., 2017).

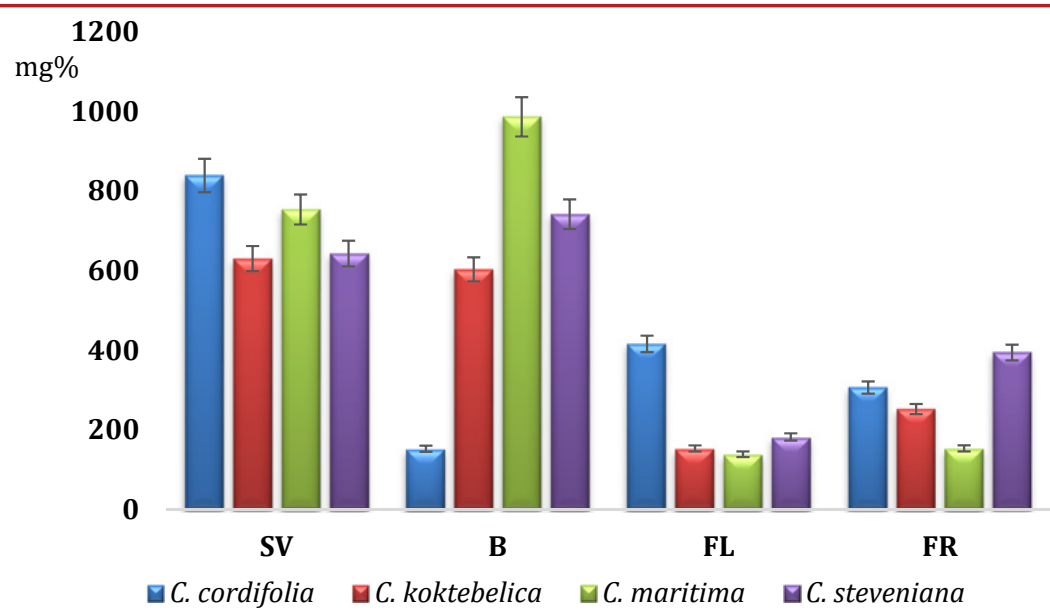

Figure 3 Total content of ascorbic acid in the above-ground part of plants of Crambe spp. $\mathrm{SV}$ - spring vegetation; B - budding stage; FL - flowering stage; FR - fruitage 
The study of the accumulation of $\beta$-carotene focused on its pharmacological properties such as anti-carcinogenic and anti-mutagenic. $\beta$-carotene an important provitamin $A$, which demonstrates the protective action in human organisms, for example, as powerful antioxidants (Bogacz-Radomska and Harasym, 2018). Content of $\beta$-carotene in raw of Crambe species determined from 0.387 to $2.408 \mathrm{mg} \%$ (Figure 4).

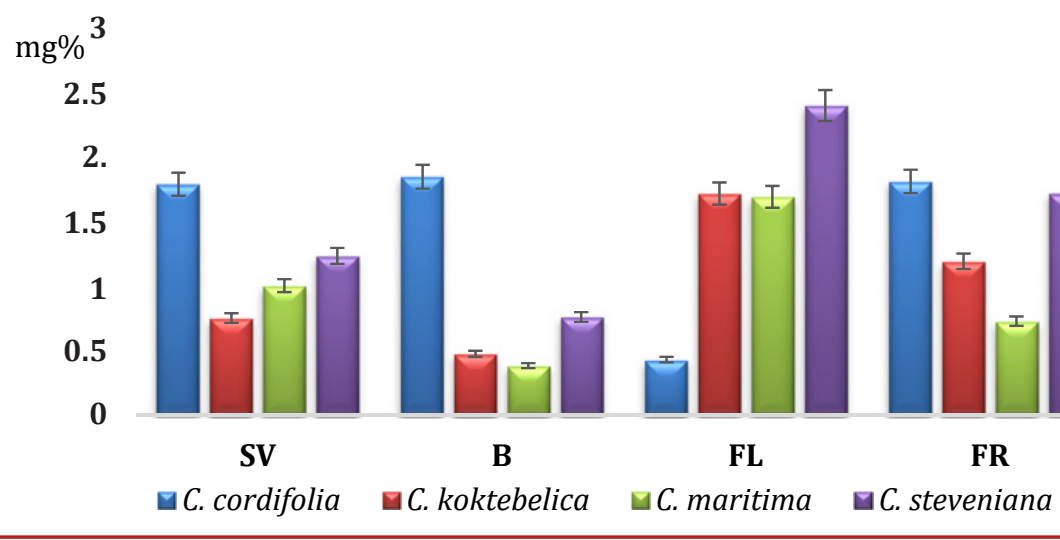

Figure 4 The content of $\beta$-carotene in the above-ground part of plants of Crambe spp. SV - spring vegetation; B - budding stage; FL - flowering stage; FR - fruitage

The study of the content of tannins in raw of investigated plants showed accumulation of them from 1.28 to $6.47 \%$ (Figure 5). Tannins are water-soluble polyphenols that are present in many plant food productions. From the one side food rich in tannins has low nutritional value, however, they also characterized by antimicrobial activity (Chung et al., 1998). Previous study concerning to Brassicaceae species showed that rapeseed meal contains $3 \%$ of tannins (Mitaru et al., 1982).

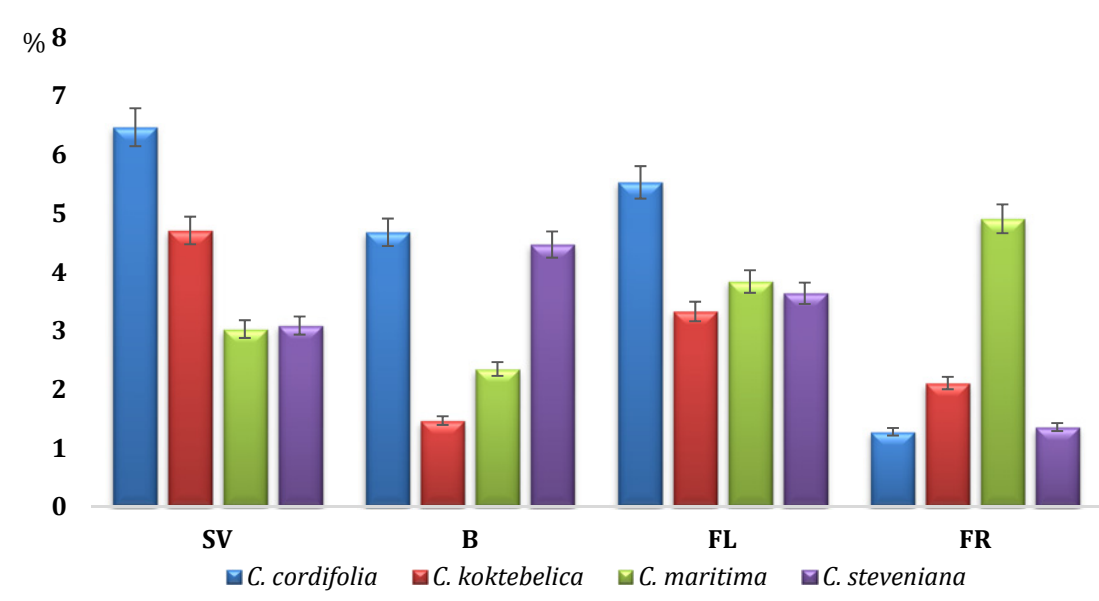

Figure 5 Total content of tannins in the above-ground part of plants of Crambe spp. $\mathrm{SV}$ - spring vegetation; $\mathrm{B}$ - budding stage; FL - flowering stage; FR - fruitage 
Accumulation of organic acids in raw of Crambe species during vegetation represented in Figure 6. We found that sum of organic acids of investigated species was from 3.12 to $6.28 \%$ depending on period of growth and species. Maximal values of this parameter were found at the period of spring vegetation for all species and at the budding stage for $C$. cordifolia. A high content of organic acids evidently due to their role in photosynthetic intermediates (López-Bucio et al., 2000).

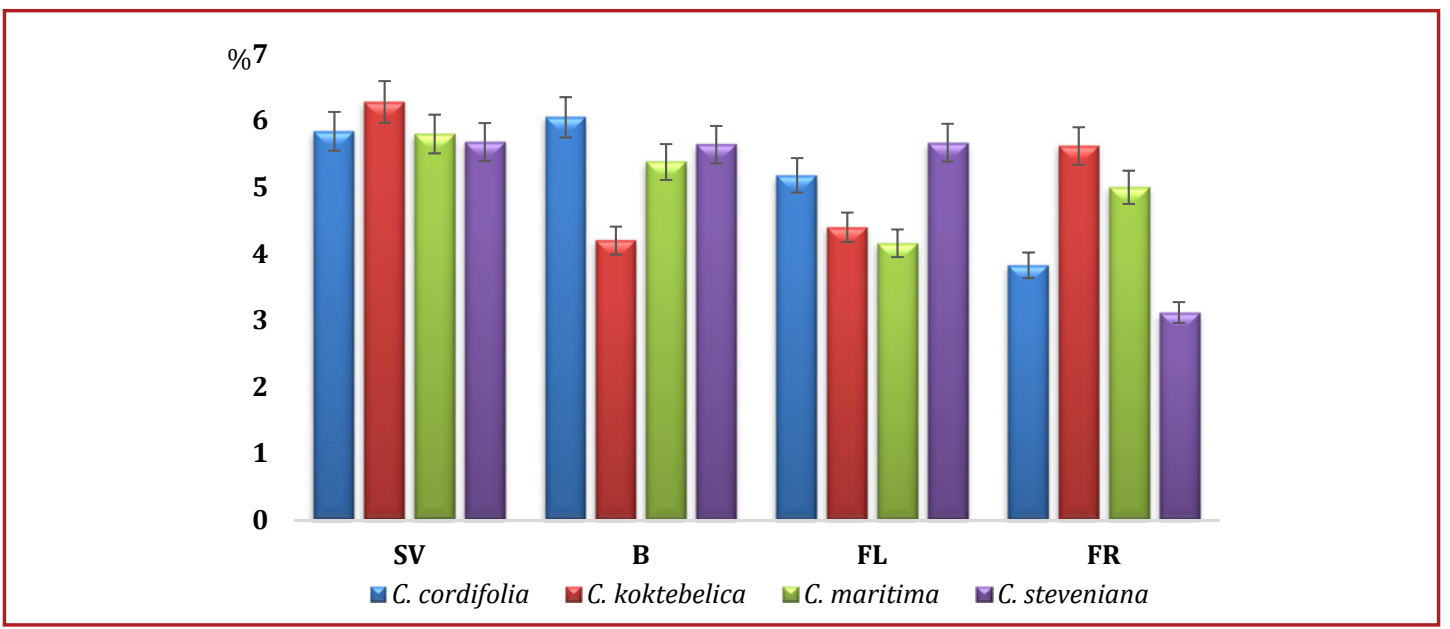

Figure 6 Total content of organic acids in the above-ground part of plants of Crambe spp. SV - spring vegetation; B - budding stage; FL - flowering stage; FR - fruitage

One of the important biochemical parameters to determine nutritional value of raw, especially food, is ash that concludes mainly mineral components (Godočiková et al., 2019). Also, according to Prochnow et al. (2009), content of ash important parameter for evaluation of quality of phytofuel. So, with increase of ash concentration heating value is decreases.

The concentration of ash in Brassicaceae plants can vary. For example, the total content of ash in stems of Lepidium sativum was $17.1 \%$ as reported Sandekar et al. (2018).

In our study content of ash for different species of Crambe was from 6.11 to $14.61 \%$ (Figure 7). It should be noted that raw $C$. cordifolia demonstrated maximal ash content at every period among other species. As reported Tutus et al. (2010), ash content of C. orientalis and C. tataria was 7.83 and $9.31 \%$, respectively.

Correlation analysis showed that between tannins and organic acids, ascorbic acid and organic acids, sugars and organic acids found a moderate correlation that was $0.52,0.46$ and 0.40 , respectively. Weak relation found between carotenoids and sugars and tannins and ash ( 0.28 for both). All other parameters showed very weak or absent correlation. 


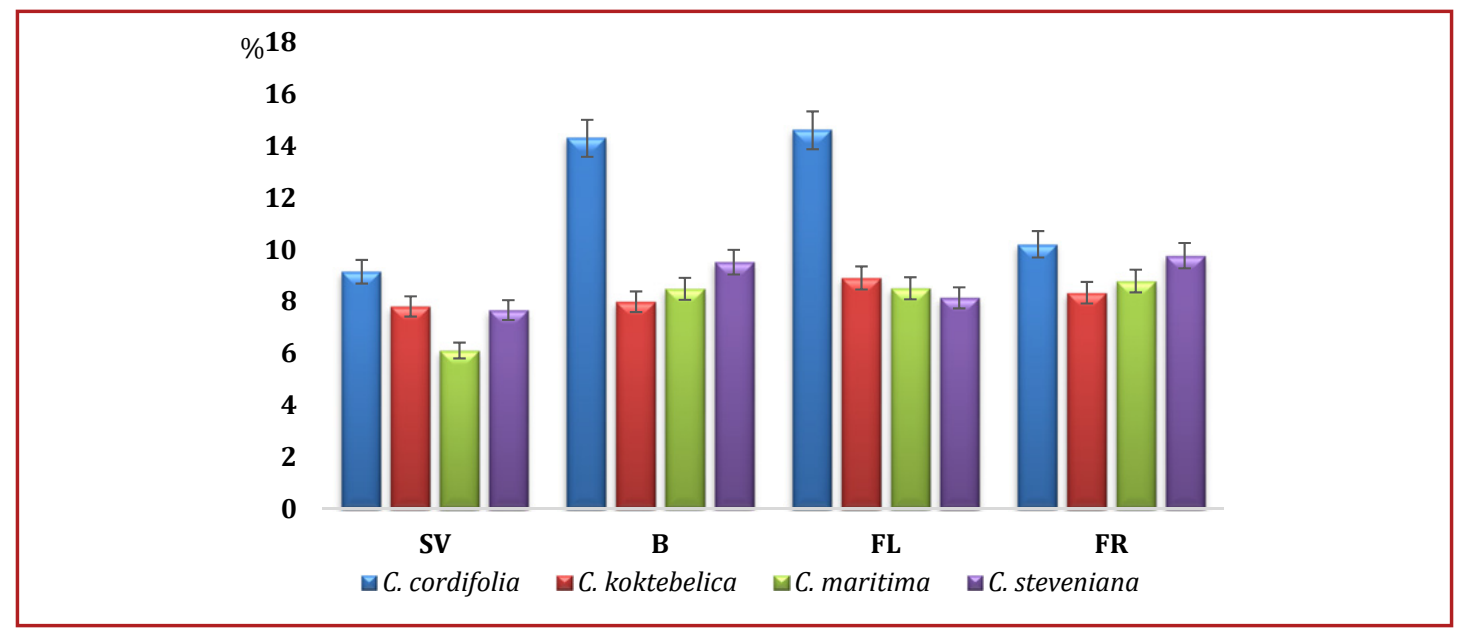

Figure 7 Total content of ash in the above-ground part of plants of Crambe spp. SV - spring vegetation; B - budding stage; FL - flowering stage; FR - fruitage

\section{Conclusions}

Investigation of the biochemical composition of four species of genus Crambe showed that investigated plants are valuable sources of nutrients. Accumulation of selected biochemical compounds in above-ground parts of these plants depends on stage of growth. Maximal values of dry matter and ascorbic acid found for C. maritima, total content of sugars and organic acids for $C$. koktebelica, carotene for C. steveniana, ash for C. cordifolia. Due to high content of ascorbic acid, carotene, sugars and other biochemical parameters of raw, Crambe species can be recommended as forage plants. Also, it required father pharmacological investigations of these plants as food and medicinal plants.

\section{Acknowledgements}

The publication was prepared with the active participation of researchers in international network AgroBioNet.

\section{References}

AVATO, P., ARGENTIERI, P.M. 2015. Brassicaceae a rich source of health improving phytochemicals. In Phytochemistry Reviews, vol. 14(6), p. 1-15. https://dx.doi.org/10.1007/s11101-015-9414-4

BOGACZ-RADOMSKA, L., HARASYM, J. 2018. $\beta$-carotene - properties and production methods. In Food Quality and Safety, vol. 2, p. 69-74. https://doi.org/10.1093/fqsafe/fyy004

CHUNG, K.T., WONG, T.Y., WEI, C.I., HUANG, Y.W., LIN, Y. 1998. Tannins in human health: a review. In Critical Reviews in Food Science and Nutrition, vol. 38(6), p. 421-464.

GODOČIKOVÁ, L., IVANIŠOVÁ, E., NOGUERA-ARTIAGA, L., CARBONELL-BARRACHINA, A.A., KAČANIOVÁ, M. 2019. Biological activity, antioxidant capacity and volitile profile of enriched Slovak chocolates. In Journal of Food and Nutrition Research, vol. 58(3), p. 283-293.

GOLONKA, I., OLEKSY, M., JUNKA, A., MATERA-WITKIEWITCZ, A., BARTOSZEWICZ, M., MUSIAL, W. 2017. Selected physicochemical and biological properties of ethyl ascorbic acid compared to ascorbic acid. In Biological and Pharmaceutical Bulletin, vol. 40(8), p. 1199-1206. https://dx.doi. org/10.1248/bpb.b16-00967 
HRYTSAJENKO, Z.M., HRYTSAJENKO, V.P., KARPENKO, V.P. 2003. Metody biologichnyh ta agrohimichnyh doslidgen roslyn i gruntiv [Methods of biological and agrochemical investigations of plants and soils]. Kyiv : Nichlava, 320 p. ISSN 966-7317-84-6. Available at: http://lib.udau.edu.ua/ handle/123456789/1547 [In Ukrainian].

ILJINSKA, A., DIDUKH, Ya., BURDA, R., KOROTCHENKO, I. 2007. Ecoflora of Ukraine. Brassicaceae (Cruciferae), Capparaceae, Resedaceae. K : Fitosotsiotsentr, 584 p. ISBN 978-966-306-140-9 [In Ukrainian].

KALISTA, M. 2017. Underutilized medicinal species of Crambe L. of the flora of Ukraine. In Agrobiodiversity for Improving Nutrition, Health and Life Quality, vol. 1, p. 216-220. http://dx.doi.org/10.15414/ agrobiodiversity.2017.2585-8246.216-220

KRISHCHENKO, V.P. 1983. Metody otsenki kachestva rastitelnoy produktsii [Methods of evaluation of plant production quality]. M : Kolos, 192 p. [In Russian].

LOKATO, V., CIMINI, S., GARA, L. 2013. Strategies to increase vitamin C in plants: from plant defense perspective to food biofortification. In Frontiers in Plant Science, vol. 4, article 152. http://dx.doi. org/10.3389/fpls.2013.00152

LOVATTO, N.M., GOULART, F.R., LOUREIRO, B.B., SPERONI, C.S., BENDER, A.B.B., GIACOMINI, S.J., NETO, J.R., da SILVA, L.P. 2017. Crambe (Crambe abissinica) and sunflower (Helianthus annuus) protein concentrates: production methods and nutritional properties for use in fish feed. In Annals of the Brazilian Academy of Sciences, vol. 89, p. 2495-2504. http://dx.doi. org/10.1590/0001-376520140630

LÓPEZ-BUCIO, J., NIETO-JACOBO, M.F., RAMÍREZ-RODRÍGUEZ, V., HERRERA-ESTRELLA, L. 2000. Organic acid metabolism in plants: from adaptive physiology to transgenic varieties for cultivation in extreme soils. In Plant Science, vol. 160, p. 1-13. https://dx.doi.org/10.1016/ $\underline{\text { S0168-9452(00)00347-2 }}$

MITARU, B.N., BLAIR, L., BELL, J.M., REICHERT, R.D. 1982. Tannin and fiber contents ofrapeseed and canola hulls. In Canadian Journal of Animal Sciences, vol. 62, p. 661-663.

PLESHKOV, B.P. 1985. Praktikum po biohimii rastenii [Plant biochemistry workshop]. Moscow: Kolos, $256 \mathrm{p}$.

PRINA, O.A. 2009. Taxonomic review of genus Crambe sect. Crambe (Brassicaceae). In Anales del Jardín Botánico de Madrid, vol. 66(1), p. 7-24. https://dx.doi.org/10.3989/ajbm.2186

PROCHNOW, A., HEIERMANN, M., PLÖCHL, M., AMON, T., HOBBS, P.J. 2009. Bioenergy from permanent grassland - a review: 2. Combustion. In Bioresource Technology, vol. 100, p. 4945-4954. https:// dx.doi.org/10.1016/j.biotech.2009.05069

RAIOLA, A., ERRICO, A., PETRUK, G., MONTI, M.D., BARONE, A., RIGANO, M.M. 2018. Bioactive compounds in Brassicaceae vegetables with a role in the prevention in chronic deseases. In Molecules, vol. 23(15), p. 1-10. https://dx.doi.org/10.3390/molecules23010015

RAKHMETOV, D., VERGUN, O., RAKHMETOVA, S., FISHCHENKO, V. 2018. Antioxidant potential of selected oil plants of Brassicaceae Burnett. In Agrobiodiversity for Improving Nutrition, Health and Life Quality, vol. 2, p. 133-139. http://dx.doi.org/10.15414/ agrobiodiversity.2018.2585-8246.133-139

RASHID, A.M., AKHTAR, N.M., ASHRAF, A., NAZIR, F., IJAZ, A., OMAR, A.N., NOOR, S., BASIT, A., TAREEN, R.B. 2018. Chemical composition and antioxidant, antimicrobial and haemolitic activities of Crambe cordifolia roots. In Farmacia, vol. 66(1), p. 165-171.

RIVELLI, A.R., CARUSO, M.K., de MARIA, S., GALGANO, F. 2017. Vitamin C content in leaves and roots of horseradish (Armoracia rusticana): seasonal variation in fresh tissues and retention as affected by storage conditions. In Emirates Journal of Food and Agriculture, vol. 29(10), p. 799-806. https://doi.org/10.9755/ejfa.2017.v29.i10.1294 
ROSA, E., DAVID, M., GOMEZ, M.H. 2001. Glucose, fructose and sucrose content in broccoli, white cabbage and Portugese cabbage grown in early and late seasons. In Journal of the Science of Food and Agriculture, vol. 81(12), p. 1145-1149. http://10.1002/jsfa.919

SANDEKAR, S.N., DEVARKAR, V.D., SHAIKH, T.J., SHAHANE, M.K., KSHIRSAGAR, U.M. 2018. Phytochemical and taxonomical studies in Lepidium sativum L. (Brassicaceae). In International Research Journal of Science and Engineering, vol. 6, p. 26-32.

SHANKAR, S., SEGARAN, G., SUNDAR, V.D.R., SETTU, S., SATHIAVELU, M. 2019. Brassicaceae - a classical review on its pharmacological review. In International Journal of Phrmaceutical Sciences Review and Research, vol. 55(1), p. 107-113.

STANKEVYCH, S. 2017. Comparative characteristic of sea cale (Brassicaceae): Crambe abissinica Hochst. With others oil-producing cabbage crops of the eastern Forest-Steppe of Ukraine. In Agrobiodiversity for improving nutrition, health and life quality, vol. 1, p. 417-421. https://dx.doi.org/10.15414/ agrobiodiversity.2017.2585-8246.417-421

TUTUS, A., COMLEKCIOGLU, N., KARAMAN, S., HAKKI ALMA, M. 2010. Chemical composition and fiber properties of Crambe orientalis and C. tataria. In International Journal of Agriculture and Biology, vol. 12, p. 286-290.

VERGUN, O., RAKHMETOV, D., FISHCHENKO, V., RAKHMETOVA, S., SHYMANSKA, O., DRUZ, N., BOGATEL, L. 2017a. The lipid content in the seeds of Brassicaceae Burnett family. In Agrobiodiversity for Improving Nutrition, Health and Life Quality, vol. 1, p. 493-497. http://dx.doi.org/10.15414/ agrobiodiversity.2017.2585-8246.493-497

VERGUN, O.M., RAKHMETOV, D.B., SHYMANSKA, O.V., FISHCHENKO, V.V., DRUZ, N.H., RAKHMETOVA, S.0. 2017b. Biohimichna harakterystyka syrovyny Camellina sativa (L.) Crantz. (Biochemical characteristic of plant raw material of Camellina sativa (L.) Crantz.). In Introdukciia Roslyn, vol. 74(2), p. 80-88. https://doi.org/10.5281/zenodo.2300770

VERGUN, O.M., RAKHMETOV, D.B., SHYMANSKA, O.V., FISHCHENKO, V.V. 2018. The accumulation of nutrients in under-ground parts of the genus of Crambe L. spp. In Introdukciia Roslyn, vol. 78(2), p. 3-11. https://doi.org/10.5281/zenodo.3377684

XIAO, Z., CODLING, E.E., LUO, Y., NOU, X., LESTER, E.G., WANG, Q. 2016. Microgreens of Brassicaceae: mineral composition and content of 30 varieties. In Journal of Food Composition and Analysis, vol. 49, p. 87-93. http://dx.doi.org/10.1016/j.jfca.2016.04.006

YERMAKOV, A.I., ARASIMOVICH, V.V., SMIRNOVA-IKONNIKOVA, M.I., YAROSH, N.P. 1972. Metody biohimicheskoho issledovaniia rastenii [The methods of biochemical investiagtions of plants]. Leningrad : Kolos, 456 p.

ZORN, K., OROZ-GUINEA, I., BORNSHEUER, U.T. 2019. Strategies for enriching erucic acid from Crambe abissinica oil by improved Candida antarctica lipase A variants. In Process Biochemistry, vol. 79, p. 65-73. https://doi.org/10.1016/j.procbio.2018.12.022 